Research Article

\title{
Socioeconomic and Environmental Impacts of Charcoal Production Activities of Rural Households in Mecha District, Ethiopia
}

\author{
Kassahun Tassie $\mathbb{D}^{1},{ }^{1}$ Berihun Misganaw $\mathbb{D}^{2},{ }^{2}$ Solomon Addisu $\mathbb{D}^{2},{ }^{2}$ and Ermias Tesfaye $\mathbb{D}^{1}$ \\ ${ }^{1}$ Bahir Dar University, College of Agriculture and Environmental Science, Department of Agricultural Economics, \\ Bahir Dar, Ethiopia \\ ${ }^{2}$ Bahir Dar University, College of Agriculture and Environmental Science, Department of Natural Resource Management, \\ Bahir Dar, Ethiopia
}

Correspondence should be addressed to Berihun Misganaw; berihunmisganaw1@gmail.com

Received 24 November 2020; Accepted 4 June 2021; Published 16 June 2021

Academic Editor: Volkan Okatan

Copyright (c) 2021 Kassahun Tassie et al. This is an open access article distributed under the Creative Commons Attribution License, which permits unrestricted use, distribution, and reproduction in any medium, provided the original work is properly cited.

\begin{abstract}
Ethiopia is one of the largest charcoal-producing countries in Africa where its urban consumers burn over 3 million tons per year. The purpose of this study was to measure the amount of charcoal produced and its related environmental and socioeconomic impact in the study area. A total of 305 respondents were selected by using a simple random sampling technique. The amount of greenhouse gas emissions from charcoal production was analyzed based on the Intergovernmental Panel on climate change quantification techniques, and the impact of charcoal production on households' income was analyzed using propensity score matching. The results revealed that the annual charcoal production rate and emission of carbon dioxide equivalent have an increasing trend at an alarming rate in the study area. From propensity score matching analysis, the economic impact of charcoal production has a positive difference of 0.43813162 as compared to nonproducers. Socioeconomic factors like land size, eucalyptus coverage, agricultural extension, market distance, and the number of oxen have a highly significant effect but variables like sex, family size, education status, credit services, and marital status had no significant effect on charcoal production. In general, even though charcoal production is economically having a positive impact on households' annual aggregate income; it has disproportionality adverse effect on the environment like air pollution in addition to sophisticated respiratory health problems. Therefore, responsible institutions and planners should have focused on the multidimensional effect of traditional charcoal production on environmental issues and sophisticated health problems especially on employed laborers and nearby residents.
\end{abstract}

\section{Background of the Study}

Globally, charcoal production trends between 1965 and 2005 show increasing production levels with Africa topping the chart [1], and approximately 1.5 billion people in developing countries drive more than $90 \%$ of their energy from charcoal for cooking and heating. Africa's charcoal production has moved from about 18.5 million tons in 1965 to about 49 million tons in 2005. Africa is closely followed by Latin America and the Caribbean, producing less than five million tons in 1965 and about 5.5 million tons in 2005 [2]. Charcoal is the primary urban fuel supply and a major source of livelihood and environmental degradation in rural areas of the African continent [3]. Production of traditional charcoal serves as a lifeline for the increasing populations in less developed countries in general and SSA nations in particular. Due to low cost as compared to other energy sources, the traditional energy alternative charcoal remains the most used, and it is expected that about 2.4 billion people rely on it [4].

Charcoal consumption in the majority of many SubSaharan Africa (SSA) is expected to double by 2030 and fuelwood consumption used for charcoal production is estimated to be 544.8 million $\mathrm{m}^{3}$ and 46.1 million tons, 
respectively [5,6]. And traditional charcoal production has been a growing concern due to its threat of deforestation, land degradation, and climate change impacts [7]. Its saturation ranges from 54 to $71 \%$ in urban areas, and it is the main fuel for more than 1 million families in SSA [8]. They added that because of the increasing use of charcoal in many countries; it is critical to assess and develop long-range charcoal policies for African and other developing countries [9]. Charcoal production is an important economic activity by providing a considerable amount of employment and also serves as a source of livelihood for most rural households [3]. The rapidly increasing demand and urbanization in many developing countries have not seen an increase in modern fuels (kerosene, LPG, natural gas, and electricity) supplied over the period, making traditional energy source use unavoidable. As a result, traditional and indigenous energy sources like charcoal have been humankind's first source and the most used [4].

In most developing nations, charcoal makers use traditional and inefficient means; they build temporary earthen kilns for earth batch [10]. The wood from natural forest and farm clearing is stacked compactly in a pit, and the stack is covered with straw or other vegetation types and then buried under a layer of soil. After some arrangement, it was kindled with burning embers introduced at one or more points at the bottom of the stack. The task of the charcoal maker throughout the ensuing burn is to open and close a succession of vent holes heating the wood while burning as little of it as possible [11].

Most environmentalists agreed and feel that the traditional method of charcoal production should be stopped because of its destructive nature as presently practiced in most nations [12]. However, Arnold and Persson [13] asserted that both rural and urban residents in less developed nations have a strong appetite for charcoal use. Therefore, attempts to ban the production or the use of charcoal will be mostly inefficient, and it has the ability to cause adverse health effects such as the respiratory illness of women and children and indoor air pollution at a significant level [14]. Charcoal producers can use free raw materials collected from the forest or other sources and turn them into a marketable commodity in high demand. Moreover, this traditional production of charcoal has a result of forest loss, and this threatens to reduce the ability of the forest to provide unlimited and multidimensional vital services [15]. For example, in Ethiopia, about 230000 tons of charcoal are used per year for domestic purposes [16].

Charcoal production in Ethiopia has limited success stories to offer because charcoal producers do not follow any standardized methods or technology. In Ethiopia, a careful assessment of charcoal production through the traditional techniques revealed an average $24 \%$ loss of timber and nontimber forest products $[16,17]$ while no studies have investigated in depth the health, environmental, and social risks associated with the production of this highly demanded energy source. Smith [18] noted that health-related impacts associated with charcoal production have focused on effects from their consumption; however, little is known about the health and socioeconomic impacts related to charcoal producers during extraction and production phases.

There is little information concerning the socioeconomic and environmental impacts of charcoal production activities of rural households in Mecha district, Ethiopia. Furthermore, the effects of charcoal production on human health and environments are not clearly understood, and also the assessment of charcoal production in the Mecha district is not well studied. Perhaps, the most serious of these is the harmful effect on the environment and climate changes, which both have consequences for human health and pollution. Therefore, this study needs to address the effect of charcoal production on the environment and human health in Mecha district, Ethiopia. Therefore, the reason that the researchers want to conduct this study is to provide answers to the following research questions: why do charcoal producers engage in charcoal production? and are charcoal producers willing to patronize alternate sources of income? Answers to these questions provide insight into how to deal with the environmental problems presented by charcoal production, which ensure the sustainable management of the environment and reduce the health impact of charcoal production.

\section{Objectives of the Study}

The specific objectives were designed as follows:

(i) To quantify the amount of carbon emitted from charcoal production

(ii) To assess the environmental impact of charcoal production

(iii) To estimate the socioeconomic impact of charcoal production on households of the study area

\section{Materials and Methods}

3.1. Description of the Study Area. The study was conducted in Mecha district, which is one of the 106 districts of the Amhara Regional State and found in the West Gojjam Zone. Mecha district is one of the 15 districts of West Gojjam Administrative Zone (see Figure 1). It is bordered in the south by Awi zone and Sekela district, in the west by south Achefer District, in the northwest by the north Achefer District, in the northeast by the Bahair Dar zuria, and in the east by Yilmana Densa district. The administrative center of the district is Merawi town. Merawi town is found 525 kilometers far from the Capital City of Ethiopia (Addis Ababa) and 35 kilometers far from the regional capital (Bahir Dar city). From the total 43 rural Kebeles in the study area, more than 18 of them have access to permanent rivers, and the district has huge groundwater potential [19].

The study district has 43 rural Kebeles. The total area of the district is about 156,027 hectares. From this, 72,178 $(46.25 \%)$ hectares (nearly half) are used for cultivation. Forestland and grazing land cover 18,547 (11.88\%) hectares and 15,591 (9.99\%) hectares, respectively [20]. Mecha district is globally located between $11^{\circ} 5^{\prime} \mathrm{N} 11^{\circ} 38^{\prime}$ latitude and $36^{\circ} 58^{\prime} 37^{\circ} 22^{\prime} \mathrm{E}$ longitude. The altitude of the district ranges 


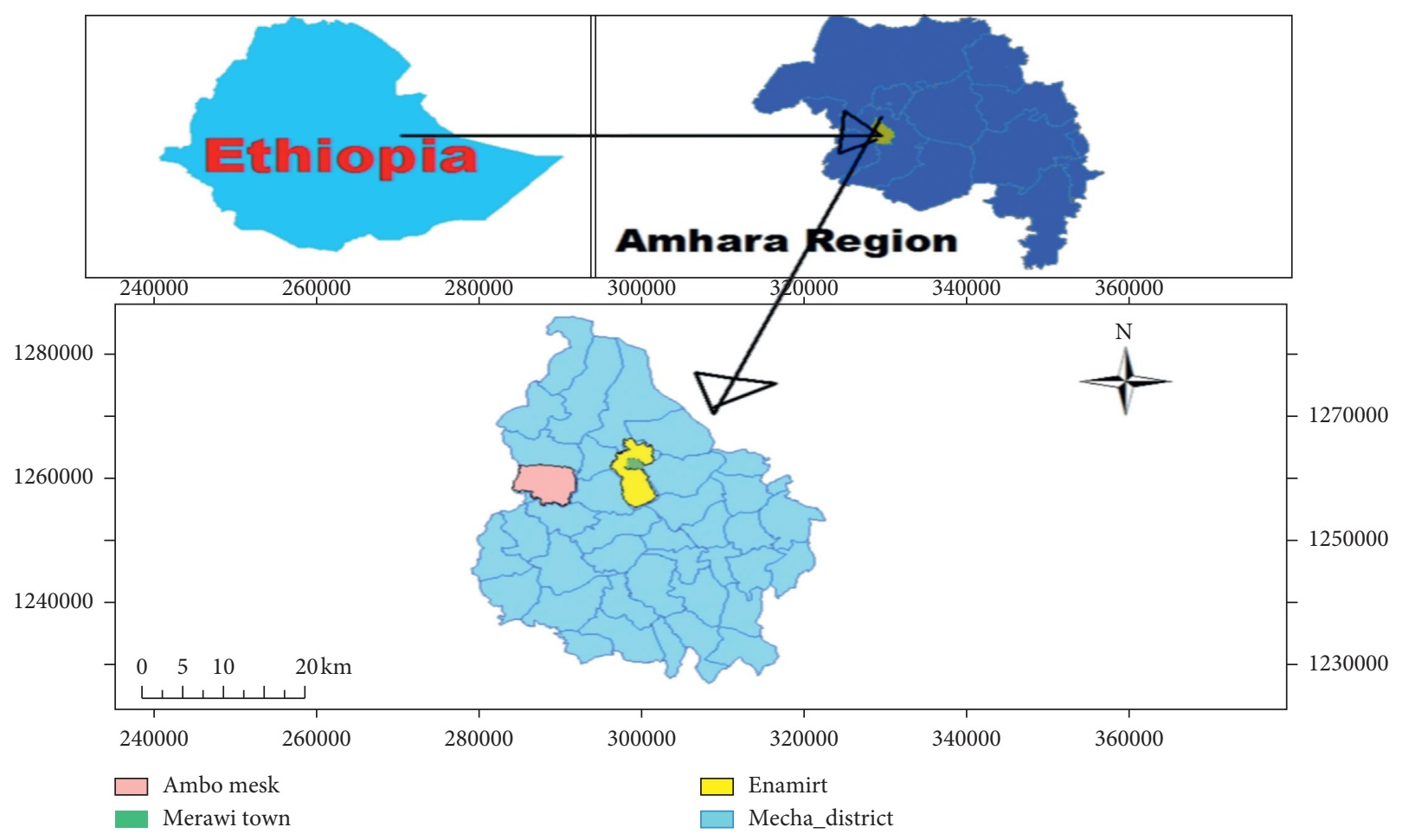

Figure 1: Map of the study area.

from 1,800 to $2,500 \mathrm{~m}$ ( $2137 \mathrm{~m}$ with an elevation) above sea level.

\subsection{Data Types, Source, and Methods of Data Collection.} The study was relying on both primary and secondary data. The primary data on the sociodemographic characteristics of respondents, health, and safety problems arising from charcoal production and other variables which were relevant to the study were collected using a pretested structured questionnaire and semistructured questionnaires through a household survey. Secondary data were collected from the Mecha district agriculture office, land administration office, trade office, environmental protection office, market information, research papers, land use regulation policy document, demographic and socioeconomic profiles, and health office which were used as data source. Secondary data collected from the above institutions were used to quantify carbon emission from charcoal production activities in the study area and to assess infectious disease prevalence related to charcoal production.

\subsection{Sample Size Determination and Sampling Techniques.} Based on the 2007 national census conducted by the CSA of Ethiopia, the district has a total population of 292,080, with men and women having 34858 and 5134 households, respectively, in 43 rural Kebeles. Ambomesk and Enamert Kebeles were selected purposively because of the greater quantity of charcoal produced than other Kebeles in the district. The sample households from two Kebeles were selected by using a simple random sampling technique based on the sample frame adopted from respective administrative
Kebele. So, respondents of charcoal producers and noncharcoal producers and employed laborers on charcoal production took part in the survey, and the total producers, nonproducers, and workers were selected randomly from two Kebeles, respectively. The population had taken as the total number of households in Mecha district, which is 39992 [21]. Accordingly, sample households from two sample Kebeles were selected by using the lottery method. The sample size was determined using the formulas used to determine sample households to be taken for household interviews used when the population is $>10000$ [22].

Sample households are the main primary data sources of this study. But determining research sample size is a function of different factors like resource, time, the purpose of the study, characteristics of the population, etc. So, to determine the sample size, we used scientific formula, and a critical component of sample size formulas is the estimation of variance in the primary variables of interest in the study [23]. For the categorical dependent variable, 5\% margin of error is acceptable, and for the continuous dependent variable, $3 \%$ margin of error is acceptable [24]. The formula is given as

$$
n=\frac{Z^{2} \mathrm{PQ}}{d^{2}}
$$

where $n$ is the required sample size (when the population is $>10,000), Z$ is the confidence interval at $95 \%$ which is 1.96 , $P=0.72$ ( $P$ refers to the proportion of the population who produce charcoal $), Q=0.28((Q=1-P)$ refers to the proportion of the population who do not produce charcoal) based on previous research findings, and $d$ refers to the desired precision of the estimates (within a range of plus or 
minus $5 \%$ ). So, using the above scientific sample size determination formula, one gets

$$
n=\frac{(1.96)^{2} \times 0.72 \times 0.28}{0.05^{2}}=n=\frac{3.8416 * 0.72 * 0.28}{0.0025} \cong 310 .
$$

Therefore, $n=310$ was the minimum sample size of charcoal producer households for reliable results. Finally, by using the proportional allocation method, the researchers were decided to take sample households from two selected Kebeles. Standing on this, a total sample of 310 households from which 150 charcoal producers and the remaining 160 nonproducers were selected randomly from generated strata sampling frame from roasters of each sample Kebele administration office and calculated proportionally based on the number of producers and nonproducers, respectively (see Table 1).

3.4. Data Analysis Methods. The data gathered from both primary and secondary sources were analyzed using qualitative and quantitative methods. Qualitative analysis usually relies on inductive reasoning processes to interpret and structure the meanings that can be derived from gathered information [25]. The data collected from the Mecha district agriculture office that was the amount of charcoal produced annually from the district at the hole to quantify the amount of greenhouse gas (GHGs) emissions from the production of charcoal were analyzed based on IPCC 2006:

$$
\mathrm{E}_{\mathrm{GHGi}}=\left(\mathrm{Fc}_{\mathrm{i}} \times \mathrm{EF}_{\mathrm{GHGi}}\right) \text {, }
$$

where $\mathrm{E}_{\mathrm{GHGi}}$ is the quantity of $\mathrm{GHG}_{\mathrm{i}}, \mathrm{Fc}_{\mathrm{i}}$ is the quantity of fuel type combusted (net), calorific value * quantity = energy input $(T)$, and $\mathrm{EF}_{\mathrm{GHGi}}$ is the emission factor for a certain $\mathrm{GHG}_{\mathrm{i}}$

The emission of GHGs from charcoal involves two phases: the production phase and the consumption phase. One kilogram of charcoal assumes to be produced from $6 \mathrm{~kg}$ wood, so sample charcoal would be measured and multiplied by 6 conducted to estimate the amount of firewood produced by the households. $\mathrm{CH}_{4}$ gas has a GWP of 21 times greater than $\mathrm{CO}_{2}$ and that of $\mathrm{N}_{2} \mathrm{O}$ is 310 times greater than $\mathrm{CO}_{2}$ [26]. Emission factors for three major GHGs from charcoal $\left(\mathrm{CO}_{2}, \mathrm{CH}_{4}\right.$, and $\left.\mathrm{N}_{2} \mathrm{O}\right)$ due to household energy consumption are given in IPCC guidelines [27].

Environmental impact of charcoal production in the study area like climate variability, mean rainfall, and temperature variability was analyzed using Microsoft Office Excel Software, and simple descriptive statistics like the percentage and mean of the data collected, employed laborer, and health problem faced were analyzed with chisquare analyzed using SPSS version 20. After data sets are collected, the researcher encodes them into STATA version 13. The socioincome impact of charcoal production was analyzed by using propensity score matching/PSM/. The findings from the analysis were presented by using descriptive statistics which include meaning, frequency distribution tables, percentages, and standard deviation methods. Finally, the conclusion and recommendation were formulated based on findings.

3.5. Impact Assessment: Propensity Score Matching Model Analysis. According to Caliendo and Kopeinig [28], there are steps in implementing PSM. These are an estimation of the propensity scores, choosing a matching algorism, checking on common support conditions, testing the matching quality, testing the standard error, and testing sensitivity analysis. The first step in the PSM method is to estimate the propensity scores. When estimating the propensity score in the binary treatment and control groups, binary logit and probit models usually yield similar results except the assumption of error terms, and the choice is based on the researchers' preference and simplicity for presenting the result [29]. Therefore, the logit model was applied to predict propensity scores for the PSM method in this study.

3.6. Specification of the Binary Logit Model. The logit distribution has more density mass in the bounds, and it is the best model to predict the probability of a household to be influenced by urban expansion, i.e., to predict propensity scores, based on which, the affected and control groups have to been matched using the nearest neighbor matching (bandwidth 4) estimator. In estimating the logit model, for impact analysis, the dependent variable is a producer that takes a value of 1 and is a nonproducer that takes the value of 0 . Yang [30] and Nguyen [31] also noted that the logit model which has more density mass in the bounds could be used to estimate the propensity score $\mathrm{p}(\mathrm{x})$. Mathematically, the model can be expressed as [32]: the logistic function is given after some mathematical work:

$$
\ln \left(\frac{P}{1-P}\right)=\beta_{0}+\beta_{i} \sum_{i=1}^{n} X_{i}+U_{i}
$$

In determining the impact of charcoal production using PSM, an impact assessment must estimate the counterfactual; that is, what would have happened if engagement in the charcoal production was never undertaken or what otherwise would have been. To determine the counterfactual, it is essential to net out the effect of charcoal production from other factors. The choice of a good counterfactual is, therefore, crucial in impact assessment. This is done through the use of control and treatment groups, and the only difference between the two groups is that treatment groups participate in charcoal production only. Propensity scores are an alternative method to evaluate the effect of receiving treatment when a random assignment of treatments to subjects is not feasible. Propensity score matching states the pairing of handling and control elements with comparable values on the propensity score, and possibly other covariates, and the discarding of all unmatched units. It is principally used to compare two groups of themes but can be applied to analyze more than two groups. As [33] suggests, PSM works well as long as the survey instrument used for measuring outcomes is identical for treatment and control participants. Hence, the success of PSM depends on the quality of data available and the variables used for matching. 
Table 1: Population and sample size of each sample Kebele.

\begin{tabular}{lccccc}
\hline $\begin{array}{l}\text { Sample } \\
\text { Kebeles }\end{array}$ & $\begin{array}{c}\text { Total number of } \\
\text { households estimated }\end{array}$ & $\begin{array}{c}\text { Estimated number of } \\
\text { charcoal producer HHs }\end{array}$ & $\begin{array}{c}\text { Estimated number of } \\
\text { noncharcoal producer HHs }\end{array}$ & \multicolumn{2}{c}{$\begin{array}{c}\text { Sample HHs } \\
\text { Producers }\end{array}$} \\
\hline Ambomesk & 1125 & 513 & 612 & 77 & 92 \\
Enamert & 931 & 482 & 449 & 73 & 68 \\
Total & 2056 & 995 & 1061 & 150 & 169 \\
\hline
\end{tabular}

As a charcoal production impact evaluation technique, PSM is based on the idea of comparing the aggregate annual income of charcoal producers with the aggregate annual income of "equivalent" charcoal producers. Since the two groups are comparable on all observed characteristics with the exception of participating in charcoal production, the differences in the aggregate annual income are attributed to the charcoal production activity. The estimated PSM for subject $e\left(x_{i}\right)(i=1, \ldots, N)$ is the conditional probability of being assigned to a particular treatment given (participated in charcoal production) and is a vector of observed covariates $x_{i}$ :

$$
\begin{aligned}
e\left(x_{i}\right) & =\operatorname{pr}\left(z_{i}=1 \mid x_{i}\right), \\
\operatorname{pr}\left(z i, \ldots, x_{1}, \ldots, x_{n}\right) & =\sum_{i=1}^{n} e(x i)^{z i}\left(1-e(x i)^{1-z i}\right),
\end{aligned}
$$

where $z_{i}=1$ for charcoal producers; $z_{i}=0$, otherwise; $x_{i}$ is the vector of observed covariates for the subject.

The treatment indicator takes either 1 or 0 , but none of these outcomes were observed for the same individual at the same time. In the urbanization program evaluation literature, these phenomena are commonly known as missing data problems [34]. In a random charcoal production participation assignment, the average treatment effect can be computed by taking the difference in means of the outcome variable between those who participate in the production and those who do not [35]. However, this procedure cannot be applied in our present case because the urbanization process in the study area followed a nonrandom process. Under this condition, an impact evaluation is usually performed by applying a more suitable nonexperimental method than an experimental method even if it has merits and demerits [36] [34]. The charcoal production income impact in the study district administration, for instance, did not collect baseline data on the outcome variable of interest and other preintervention characteristics of displaced farm households because of charcoal production and not producing charcoal by farm households in the study area. (In the presence of both baseline and follow-up survey data, a more robust procedure for impact evaluation would be a difference-in-difference (DID) or DID in combination with PSM.) Thus, we have to rely on a PSM that can identify comparable treatment and comparison observations using cross-sectional data [37].

The propensity score is a probability range in values from 0 to 1 . Therefore, if PSM was used in a randomized experiment comparing two groups, then the propensity score for each respondent in the study would be 0.50 . This is because each respondent would be randomly assigned to either the treated or the control group with a 50\% probability. In this study, the PSM was used to evaluate the impact of charcoal production on the income of charcoalproducing farm households. If it denotes the potential outcome conditional on charcoal production and denotes the potential outcome conditional on charcoal nonproducing, the impact of charcoal production is given by

$$
\Delta=Y_{1}-Y_{0}
$$

3.6.1. Estimating the Propensity Score (PS). The propensity score is defined as the conditional probability of receiving income from charcoal production given pretreatment characteristics [37]. The propensity scores were computed using binary logit regression models given as

$$
P(X)=\operatorname{Pr}\left\{D=\frac{1}{X}\right\}=E\left\{\frac{D}{X}\right\},
$$

where $D=(0,1)$ is the indicator of exposure to charcoal production characteristics (dependent variable). That is, $D=1$ if it is exposed to charcoal producer farm households, and $D=0$ if it does not participate in charcoal production until this survey was conducted; $X_{i}$ is the multidimensional vector of observed characteristics (explanatory variables).

These explanatory variables are expected to jointly determine the probability to participate in charcoal production in the study district. The explanatory variables considered in this study were based on theory and from the review of studies.

3.6.2. Matching the Unit Using the Propensity Score. After the propensity score is estimated and computed for each unit, the next step is the actual matching. The nearest neighbor matching uses the propensity score of similar individuals in the treated and control groups to construct the counterfactual outcome. Because of this, the nearest neighbor matching method was used to match. The main benefit of this approach is the lower change which is reached for more data is used. The matching estimator is given as

$$
\begin{aligned}
\tau^{M} & =\frac{1}{N^{T}} \sum i \operatorname{ET}\left\{Y_{i}^{T}-\sum i \operatorname{ETW}_{i j} Y_{j}^{c}\right\} \\
& =\frac{1}{N^{T}}\left\{\sum i \mathrm{ETY}^{T}-\sum i \operatorname{ET} \sum i \operatorname{ETW}_{i j} Y_{j}^{c}\right\} .
\end{aligned}
$$

(i) $i, E, T, N_{i}^{c}$ denote the numbers of charcoal producers matched with observation and define the weights $W_{i j}=1 / N_{i}^{c} i f j \mathrm{EC}(i)$, and $W_{i j}=0$, otherwise 
(ii) M stands for the nearest neighbor matching, and the number of units in the treated group is denoted by $N^{T}$

One of the major advantages of this method is that the absolute difference between the estimated propensity scores for the control and treatment groups is minimized.

3.6.3. Estimating the Impact (Average Treatment Effect on the Treated (ATT). Heckman et al. [38] present several essential preconditions in order to get reliable and low-bias impact estimates using PSM. These preconditions included the following: (1) data are collected using identical questionnaires for both groups during the same period, (2) treatment and comparison observations share a comparable socioeconomic, demographic, and agroecological setting, and (3) relevant variables related to treatment and outcome are included in the propensity score function. The dataset used in our study clearly meets precondition (1) because an identical survey instrument is used to elicit data from both control and treatment groups. Precondition (2) is also met because as noted earlier the survey data for our study comes from households (both displaced and nondisplaced farm households) residing in the same study area. To meet precondition (3), the propensity score is estimated by using sample households 'observable characteristics which are relevant for both participation in the urbanization program and the outcome variable of interest (see Table 1) [34, 38]. Propensity scores were estimated by a logit model with the dependent variable coded as 1 for displaced households because of urbanization and 0 for nondisplaced households, and independent variables comprised of several preintervention characteristics. After the propensity scores were estimated, a kernel matching estimator was used to compute the average impact of the program among IFSP households. (The choice of a matching method is a difficult exercise and largely depends on the data at hand. The quality of matching can be compared using different statistical tests. In this paper, kernel matching with a bandwidth of 0.25 was chosen based on different criteria discussed in the Results section.) In particular, the average treatment effect on the treated was computed using the following equation:

$$
\begin{aligned}
\mathrm{ATT} & =E(\Delta \mid D=1, X)=E\left(Y_{1}-Y_{0} \mid D=1, X\right) \\
& =E\left(Y_{1} \mid D=1, X\right)-E\left(Y_{0} \mid D=0, X\right),
\end{aligned}
$$

where $D=1$ denotes program participation in charcoal production, and $\mathrm{X}$ is a set of conditioning variables on which the subjects were matched.

Equation (10) would have been easy to estimate except for the equation $\mathrm{E}\left(Y_{0} \mid D=1, X\right)$. This is the mean of the counterfactual and denotes what the outcome would have been among participants on charcoal production had they do not participate in the charcoal production (nonproducer).

PSM provides a way of estimating this equation. A unique advantage of PSM is that instead of matching subjects on a vector of characteristics, we only need to match on a single item the propensity score that measures the probability of participating in the charcoal production. Given that the Conditional Independence Assumption and the common support assumption hold, then we estimate the mean effect of the charcoal production on annual income through the mean difference in the outcomes of the matched pairs:

$$
\operatorname{ATT}=\frac{1}{N_{1}} \sum_{i=1}^{N_{1}}\left(y_{1 i}-\sum_{j=1}^{N_{0}} w_{i j} y_{0 j}\right)
$$

where $w_{i j} E[0,1]$ and $\sum_{j=1}^{N_{0}} w_{i j}=1, N_{1}$ is the number of producers, $N_{0}$ is the number of nonproducers, $i$ is the index of producers, $j$ is the index of nonproducers, and $W_{i j}$ is the weights.

3.7. Definition of Variables and Expected Sign. Based on reviews of empirical studies, like any other economic activity, the household's participation in charcoal production is expected to be affected by household sociodemographic factors, attitudes of households toward the determinants of charcoal production, and other factors. Based on our empirical review findings, the following explanatory variables are identified for this study, and the hypotheses of their expected signs are defined as shown in Table 2.

\section{Results and Discussion}

4.1. Descriptive Statistics Analysis of Sample Households. From the total sample of the study, 5 responses from nonproducers were dropped out because of incompleteness and errors, and the analysis was made on 305 samples. The simple descriptive statistical analysis results of the socioeconomic characteristic of charcoal producers and nonproducer households in the Mecha district are presented in Table 3. Some of the characteristics discussed here are sex, marital status, age, educational level, household size, land size, eucalyptus tree coverage, market distance, number of oxen, credit service, and extension service.

As represented in Table 3, considering the age range of the people carrying out the charcoal production, it was discovered that people who are between the age range of 35-45 years have the highest percentage of $52.7 \%$ which implies that they are more involved in the production of charcoal than those who are of other age ranges in Mecha district, and the next set of people are those who are in the age range of 46-55 years which have the record of $24.7 \%$ followed by those who are less than 35 years of age with the percentage of $21.3 \%$, and the least age range involved are the people above $>55$ years of age having a percentage of $1.3 \%$.

This result is in line with [39] findings that reported that $20(59 \%)$ of the respondents are in the ages of 20-39 years; this is not surprising since this is generally the active age group in human life; in particular, the activity is an energy exacting one and different from practices in other parts of the world most especially in Asia as reported by [40] where most of the people involved in charcoal production in Asia are those who are in the active age range of 50-60 years. 
TABle 2: Definition and measurement of independent variables in PSM.

\begin{tabular}{|c|c|c|c|}
\hline Variable & Definition & Measurement & Hypothesis \\
\hline Sex & Sex of household head & 1 male, 0 female & + Positive \\
\hline Education & Educational level of the household head & Level category & -Negative \\
\hline Family size & Household family size & Number & $+1-$ \\
\hline Land size & Household agricultural landholding size & hectares & -Negative \\
\hline Eucalyptus coverage & Owned farm size covered with eucalyptus & hectares & +Positive \\
\hline Age & Age of household head & years & -Negative \\
\hline Marital status & Marital status of household & Level category & +Positive \\
\hline No. of oxen & Number of oxen per household head & Number & -Negative \\
\hline Credit service & Access to credit service of household head & $1=$ yes, $2=$ no & +Positive \\
\hline Extension service & Educational level of the household head & Level category & -Negative \\
\hline Market distance in $\mathrm{km}$ & Market distance in $\mathrm{km}$ of household head & Number & -Negative \\
\hline
\end{tabular}

TABle 3: Age distribution of the household heads of charcoal producers and nonproducers.

\begin{tabular}{|c|c|c|c|c|c|c|c|}
\hline \multirow[t]{2}{*}{ Variables } & \multirow[t]{2}{*}{ Age category } & \multicolumn{2}{|c|}{$\begin{array}{l}\text { Nonproducer } \\
\quad(N=155)\end{array}$} & \multicolumn{2}{|c|}{ Producer $(N=150)$} & \multicolumn{2}{|c|}{ Total $(N=305)$} \\
\hline & & $N$ & $\%$ & $N$ & $\%$ & $N$ & $\%$ \\
\hline \multirow{4}{*}{ Age } & $<35$ & 22 & 14.2 & 32 & 21.3 & 54 & 17.7 \\
\hline & $35-45$ & 83 & 53.5 & 79 & 52.7 & 162 & 53.1 \\
\hline & $46-55$ & 39 & 25.2 & 37 & 24.7 & 76 & 24.9 \\
\hline & $>55$ & 11 & 7.1 & 2 & 1.3 & 13 & 4.3 \\
\hline
\end{tabular}

Source: survey result (2019).

As represented in Table 4, it was, therefore, observed that the percentage of the married people involved is very much higher than the other group of people involved in the charcoal production as it is about $87.3 \%$; the percentage of another group of people involved is very minimal; the singles involved are about $4 \%$, the widowers are about $5.3 \%$, and the divorced people are about $3.3 \%$. This result is similar to the report of [41] who reported that the percentage of the married people involved is very much higher than the other group of people involved in the production as it is about $83.0 \%$, the singles involved are about $7 \%$, the widowers are about $5 \%$, and the widows and divorced people are about $4 \%$ and $1 \%$, respectively. Reference [39] also found similar results where $73 \%$ of charcoal producers in Borgu local government area of Niger State, Nigeria, are married while $24 \%$ are single.

As represented in Table 5, the educational status of the people having the charcoal production was also taken into consideration in this study, where it was observed that the highest percentage of the people has a reading and writing (informal education) education, about $52.0 \%$ of them, followed by those with illiterate (no formal education), having a percentage of $45.3 \%$ and those who have primary school and secondary school education with the percentage of $2.0 \%$ and $0.7 \%$, respectively.

This result is in line with the report of [41] who reported that charcoal production mostly involves people with no education; from his report, he affirmed that junior class dropouts had the highest number of frequencies in his research.

As represented in Table 6, only $56.7 \%$ of charcoal producer households access agricultural extension service which means that the remaining $43.3 \%$ had not addressed agricultural extension service since most charcoal producer farmer's primary occupation was charcoal production rather than farming activity. Charcoal producer households' access to agricultural extension service is not statistically significant as the results are not significant at 5\% $(P>0.102)$. But noncharcoal producer households' access to agricultural extension service is statistically significant as the results are significant at $1 \%(P \leq 0.001)$. As represented in Table 6, also 93.3\% of charcoal producer households and $91.0 \%$ of noncharcoal producer households access credit service from the formal and informal financial institutions; charcoal producer and nonproducer households' access to credit service is statistically significant at $1 \%(P \geq 0.001)$.

As represented in Table 7 , only $4 \%$ of farmers incorporated in this study were females who are involved in the production of charcoal in the study area, but the remaining and the largest portion of charcoal producer farmers incorporated in this study were males accounting for $96.0 \%$ which means that female household heads mostly participated in farming activities rather than participating in charcoal production.

This result is in line with of results of [39] who reported that 34 respondents are involved in charcoal production in the study area and most of the respondents (31(91\%)) are males; this is as a result of the tedious nature of commercial charcoal production which requires a lot of energy. The study [42] reported that the producers are mostly male (69.20-85.10\%).

The result in Table 8 shows that statistically there is a significant difference between a charcoal producer and noncharcoal producer in terms of household eucalyptus coverage, number of oxen, and amount of aggregate annual income, and market distance. Furthermore, there is no 
TABle 4: Marital status of household heads of nonproducers and charcoal producers.

\begin{tabular}{|c|c|c|c|c|c|c|c|}
\hline \multirow[t]{2}{*}{ Variables } & \multirow[t]{2}{*}{ Category } & \multicolumn{2}{|c|}{$\begin{array}{l}\text { Nonproducer } \\
\quad(N=155)\end{array}$} & \multicolumn{2}{|c|}{ Producer $(N=150)$} & \multicolumn{2}{|c|}{ Total $(N=305)$} \\
\hline & & $N$ & $\%$ & $N$ & $\%$ & $N$ & $\%$ \\
\hline \multirow{4}{*}{ Marital status } & Married & 133 & 85.8 & 131 & 87.33 & 264 & 86.5 \\
\hline & Single & 3 & 1.9 & 6 & 4 & 9 & 3 \\
\hline & Widow & 15 & 9.7 & 8 & 5.33 & 23 & 7.5 \\
\hline & Divorced & 4 & 2.6 & 5 & 3.33 & 9 & 3 \\
\hline
\end{tabular}

Source: survey result (2019).

TABLE 5: Literacy level of heads of noncharcoal producers and producer households' heads.

\begin{tabular}{|c|c|c|c|c|c|c|c|}
\hline \multirow[t]{2}{*}{ Variables } & \multirow[t]{2}{*}{ Category } & \multicolumn{2}{|c|}{$\begin{array}{l}\text { Nonproducer } \\
\quad(N=155)\end{array}$} & \multicolumn{2}{|c|}{$\begin{array}{l}\text { Producer } \\
(N=150)\end{array}$} & \multicolumn{2}{|c|}{ Total $(N=305)$} \\
\hline & & $N$ & $\%$ & $N$ & $\%$ & $N$ & $\%$ \\
\hline \multirow{4}{*}{ Education status of $\mathrm{HH}$} & Illiterate & 84 & 54.2 & 68 & 45.3 & 152 & 49.75 \\
\hline & Reading and writing & 70 & 45.2 & 78 & 52.0 & 148 & 48.60 \\
\hline & Primary school & 1 & 0.6 & 3 & 2.0 & 4 & 1.30 \\
\hline & Secondary and above & 0 & 0.0 & 1 & 0.7 & 1 & 0.35 \\
\hline
\end{tabular}

Source: survey result (2019).

TABLE 6: Extension and credit service access of heads of nonproducer and producers.

\begin{tabular}{|c|c|c|c|c|c|c|c|}
\hline \multirow[t]{2}{*}{ Variables } & \multirow[t]{2}{*}{ Category } & \multicolumn{2}{|c|}{$\begin{array}{l}\text { Nonproducer } \\
\quad(N=155)\end{array}$} & \multicolumn{2}{|c|}{ Producer $(N=150)$} & \multicolumn{2}{|c|}{ Total $(N=305)$} \\
\hline & & $N$ & $\%$ & $N$ & $\%$ & $N$ & $\%$ \\
\hline \multirow{2}{*}{ Extension service } & No & 25 & 16.1 & 65 & 43.3 & 90 & 29.5 \\
\hline & Yes & 130 & 83.9 & 85 & 56.7 & 215 & 70.5 \\
\hline Chi $^{2}$ significance & \multicolumn{3}{|c|}{0.000} & \multicolumn{4}{|c|}{0.102} \\
\hline \multirow{2}{*}{ Credit service } & No & 14 & 9.0 & 10 & 6.7 & 24 & 7.9 \\
\hline & Yes & 141 & 91.0 & 140 & 93.3 & 281 & 92.1 \\
\hline $\mathrm{Chi}^{2}$ significance & & 000 & & \multicolumn{4}{|c|}{0.000} \\
\hline
\end{tabular}

Source: survey result (2019).

TABLE 7: Sex of heads of noncharcoal producer and charcoal producer households.

\begin{tabular}{|c|c|c|c|c|c|c|c|}
\hline \multirow[t]{2}{*}{ Variables } & \multirow[t]{2}{*}{ Category } & \multicolumn{2}{|c|}{$\begin{array}{l}\text { Nonproducer } \\
\quad(N=155)\end{array}$} & \multicolumn{2}{|c|}{ Producer $(N=150)$} & \multicolumn{2}{|c|}{ Total $(N=305)$} \\
\hline & & $N$ & $\%$ & $N$ & $\%$ & $N$ & $\%$ \\
\hline \multirow{2}{*}{ Sex } & Male & 139 & 89.7 & 144 & 96.0 & 283 & 92.8 \\
\hline & Female & 16 & 10.3 & 6 & 4 & 22 & 7.2 \\
\hline
\end{tabular}

Source: survey result (2019).

statistically significant difference between a charcoal producer and noncharcoal producer in terms of household land size and family size. Accordingly, household eucalyptus coverage, number of oxen, and amount of aggregate annual income are significant at a $1 \%$ significance level, while market distance is significant at a $5 \%$ significance level.

As represented in Table 8, considering the family size of the people carrying out the charcoal production, it was discovered that people have average an family size of 4.96 , and it was less than the average family size of noncharcoal producers, which accounted for 5.23. As represented in Table 8 also, people carrying out the charcoal production have an average number of oxen of 1.7 , which is slightly less than the average number of oxen of noncharcoal producers which accounted for 1.9. Furthermore, in Table 8, the average land size in a hectare of charcoal producer farmers was 1.63 whereas the average land sizes of noncharcoal producer farmers were 1.7 hectares. In line with this, as we get data from Mecha district agricultural office, the average landholding at the district level is 1.5 ha per household and ranges from 0 to 3 ha among the farmers in the area.

\subsection{Carbon Emission Quantification from Charcoal}

Production. The researchers accessed organized data on the annual amount of charcoal production from Mecha district agricultural office starting from 2014 and are enforced to use the available data only because of the inaccessibility of the 
TABLE 8: Summary statistics and mean difference test on continuous variables.

\begin{tabular}{|c|c|c|c|c|c|c|c|c|c|}
\hline \multirow[t]{2}{*}{ Explanatory variables } & \multicolumn{2}{|c|}{$\begin{array}{l}\text { Nonproducer } \\
\quad(N=155)\end{array}$} & \multicolumn{2}{|c|}{$\begin{array}{l}\text { Producer } \\
(N=150)\end{array}$} & \multicolumn{2}{|c|}{ Total $(N=305)$} & \multicolumn{2}{|c|}{ Mean difference } & \multirow[t]{2}{*}{$T$-value } \\
\hline & Mean & $(\mathrm{SD})$ & Mean & $(\mathrm{SD})$ & Mean & (SD) & Mean & $(\mathrm{SD})$ & \\
\hline Family size & 5.23 & 1.506 & 4.96 & 1.583 & 5.0983 & 1.5486 & 0.27 & -0.077 & $.202 \mathrm{~ns}$ \\
\hline Land size & 1.713 & 0.578 & 1.629 & 0.517 & 1.6721 & 0.5497 & 0.084 & 0.061 & $.289 \mathrm{~ns}$ \\
\hline Eucalyptus & 0.469 & 0.318 & 0.812 & 0.256 & 0.63793 & 0.33661 & -0.343 & 0.062 & $0.000^{* *}$ \\
\hline No. of oxen & 1.883 & 0.44 & 1.686 & 0.58 & 1.786 & 0.5229 & 0.197 & -0.14 & $0.000^{* *}$ \\
\hline Market distance & 5.23 & 1.23 & 4.97 & 1.00 & 5.1054 & 1.1303 & 0.26 & 0.23 & $0.046^{*}$ \\
\hline Annual income & 42496.7 & 7971.6 & 65230 & 11497 & 53677 & 15052 & -22733 & -3525.4 & $0.000^{* *}$ \\
\hline
\end{tabular}

Source: survey result (2019); ${ }^{* *}$ significant at $1 \%,{ }^{*}$ at $5 \%$, and ns denotes nonsignificance levels, respectively. Note: means and standard deviations (SD) are adjusted for sampling weights.

amount of annual charcoal production data from 2011 to 2013. The five-year data (2014-2018) amount of charcoal produced annually from the Mecha district as a whole was collected from the Mecha district agriculture office. The data were analyzed based on IPCC 2006 as expressed in equation (3). Therefore, quantity of GHGi = quantity of charcoal (tons) $\times$ emission factors for three major GHGs from charcoal $\left(\mathrm{CO}_{2}, \mathrm{CH}_{4}\right.$, and $\left.\mathrm{N}_{2} \mathrm{O}\right)$ given in IPCC guideline [27]. To quantify the total emissions of carbon dioxide equivalent $\left(\mathrm{CO}_{2} \mathrm{e}\right), \mathrm{CH}_{4}$ and $\mathrm{N}_{2} \mathrm{O}$ are multiplied by 21 and 310, respectively, but $\mathrm{CO}_{2}$ is taken as it is since $\mathrm{CH}_{4}$ gas has a GWP of 21 times greater than $\mathrm{CO}_{2}$ and that of $\mathrm{N}_{2} \mathrm{O}$ is 310 times greater than $\mathrm{CO}_{2}$ [26]. The amounts of greenhouse gas (GHG) emissions from charcoal production were quantified based on the above formula and discussed in Tables 9-14.

As stated in Table 9, 15096 tons of charcoal produced by households in the Mecha district per annum in 2014 is estimated to have been produced from 90576 tons of wood (15096*6). On this basis, total greenhouse gas emissions due to charcoal production and consumption per year amount to 24411.02 tons of $\mathrm{CO}_{2} \mathrm{e}$.

As stated in Table 10, 20282.2 tons of charcoal produced by households in the Mecha district per annum in 2015 is estimated to have been produced from 121693.2 tons of wood $\left(20282.2^{*} 6\right)$. On this basis, total greenhouse gas emissions due to charcoal production and consumption per year amount to 32797.37 tons of $\mathrm{CO}_{2} \mathrm{e}$.

As stated in Table 11, 25060 tons of charcoal produced by households in the Mecha district per annum in 2016 is estimated to have been produced from 150360 tons of wood $\left(25060^{*} 6\right)$. On this basis, total greenhouse gas emissions due to charcoal production and consumption per year amount to 40523.32 tons of $\mathrm{CO}_{2} \mathrm{e}$.

As stated in Table 12, about 53270.0 tons of charcoal produced by households in the Mecha district per annum in 2017 is estimated to have been produced from 319320 tons of wood $\left(53270.0^{*} 6\right)$. On this basis, total greenhouse gas emissions due to charcoal production and consumption per year amount to 86140.36 tons of $\mathrm{CO}_{2} \mathrm{e}$.

As stated in Table 13, 50940.0 tons of charcoal produced by households in the Mecha district per annum in 2018 is estimated to have been produced from 305640 tons of wood $\left(50940.0^{*} 6\right)$. On this basis, total greenhouse gas emissions due to charcoal production and consumption per year amount to 82371.91 tons of $\mathrm{CO}_{2} \mathrm{e}$.
Table 14 shows a total of 164648.2 tons of charcoal produced by households in the Mecha district from 2014 to 2018. On this basis, total greenhouse gas emissions due to charcoal production and consumption for the last five years amount to 266244 tons of $\mathrm{CO}_{2} \mathrm{e}$ and on average 53248.8 tons of $\mathrm{CO}_{2} \mathrm{e}$ emitted per year. Generally, from these five years' data, the quantity of charcoal production increases year to year, and the same direction changes in the total emission of $\mathrm{CO}_{2} \mathrm{e}$.

\subsection{Environmental and Health Impact of Charcoal Production} in the Study Area. To realize the environmental impact of charcoal production on local temperature and rainfall variability of the study area, rainfall and temperature data were provided from Bahir Dar Regional metrology service agency. The rainfall and temperature data obtained from Bahir Dar Regional metrology service agency was analyzed using a Microsoft Excel spreadsheet and stated in Figure 2.

As represented in Figure 2, the annual minimum temperature has almost a constant trend before 2011 but has an increasing trend especially after 2011 since charcoal production started hugely in 2011 in the study area.

As represented in Figure 2, the annual maximum temperature has also an increasing trend especially after 2011 since charcoal production started massively in 2011 in the study area.

As represented in Figure 3, the average annual rainfall had a fluctuated trend from 2011 to 2015 and an increasing trend especially after 2016 in the study area. This implies that charcoal production affects local temperature negatively but the annual rainfall trend is not affected by the amount of charcoal produced in the study area.

As represented in Table 15, 86\% of respondents said that the reason behind engaging in charcoal production is the primary occupation rather than other livelihood systems, and higher income was the generation from charcoal production rather than other livelihood systems in the study area. The remaining $10 \%$ of respondents said that they should change unwanted branches, waste, and tree pieces from the eucalyptus tree trade to charcoal and to get additional income. About $6 \%$ of respondents said that higher market demand for charcoal production in the study area and near market enforce them to produce charcoal.

As represented in Table 16, it shows that the majority (66\%) of the charcoal producers get wood for charcoal 
TABle 9: Annual GHG emissions due to charcoal production and consumption by 2014.

\begin{tabular}{lcccc}
\hline Quantity of charcoal (tons) & Type of GHG & EF & Emissions (year) (tons) & $\mathrm{CO}_{2} \mathrm{e}$ emissions (year) (tons) \\
\hline 15096 & $\mathrm{CO}_{2}$ & 1.5130000 & 22840.248 & 22840.248 \\
15096 & $\mathrm{CH}_{4}$ & 0.0041400 & 62.49744 & 1312.44624 \\
15096 & $\mathrm{~N}_{2} \mathrm{O}$ & 0.0000552 & 0.8332992 & 258.322752 \\
& & & 24411.02 \\
\hline
\end{tabular}

TAble 10: Annual GHG emissions due to charcoal production and consumption by 2015.

\begin{tabular}{lcccc}
\hline Quantity of charcoal (tons) & Type of GHG & EF & Emissions (year) (tons) & $\mathrm{CO}_{2} \mathrm{e}$ emissions (year) (tons) \\
\hline 20282.2 & $\mathrm{CO}_{2}$ & 1.5130000 & 30686.9686 & 30686.9686 \\
20282.2 & $\mathrm{CH}_{4}$ & 0.0041400 & 83.968308 & 1763.334468 \\
20282.2 & $\mathrm{~N}_{2} \mathrm{O}$ & 0.0000552 & 1.11957744 & 347.0690064 \\
& & & 32797.37 \\
\hline
\end{tabular}

TABLE 11: Annual GHG emissions due to charcoal production and consumption by 2016.

\begin{tabular}{lrrrr}
\hline Quantity of charcoal (tons) & Type of GHG & EF & Emissions (year) (tons) & $\mathrm{CO}_{2} \mathrm{e}$ emissions (year) (tons) \\
\hline 25060 & $\mathrm{CO}_{2}$ & 1.5130000 & 37915.78 & 37915.78 \\
25060 & $\mathrm{CH}_{4}$ & 0.0041400 & 103.7484 & 2178.7164 \\
25060 & $\mathrm{~N}_{2} \mathrm{O}$ & 0.0000552 & 1.383312 & 428.82672 \\
& & & 40523.32 \\
\hline
\end{tabular}

TAвLe 12: Annual GHG emissions due to charcoal production and consumption by 2017.

\begin{tabular}{lcccc}
\hline Quantity of charcoal (tons) & Type of GHG & EF & Emissions (year) (tons) & $\mathrm{CO}_{2} \mathrm{e}$ emissions (year) (tons) \\
\hline 53270.0 & $\mathrm{CO}_{2}$ & 1.5130000 & 80597.51 & 80597.51 \\
53270.0 & $\mathrm{CH}_{4}$ & 0.0041400 & 220.5378 & 4631.2938 \\
53270.0 & $\mathrm{~N}_{2} \mathrm{O}$ & 0.0000552 & 2.940504 & 911.55624 \\
& & & 86140.36 \\
\hline
\end{tabular}

TAвLe 13: Annual GHG emissions due to charcoal production and consumption by 2018.

\begin{tabular}{lrrrr}
\hline Quantity of charcoal (tons) & Type of GHG & EF & Emissions (year) (tons) & CO $_{2} \mathrm{e}$ emissions (year) (tons) \\
\hline 50940.0 & $\mathrm{CO}_{2}$ & 1.5130000 & 77072.22 & 77072.22 \\
50940.0 & $\mathrm{CH}_{4}$ & 0.0041400 & 210.8916 & 4428 \\
50940.0 & $\mathrm{~N}_{2} \mathrm{O}$ & 0.0000552 & 2.811888 & 871.68528 \\
& & & 82371.91 \\
\hline
\end{tabular}

TABle 14: Summary of annual GHG emissions due to charcoal production from 2014 to 2018.

\begin{tabular}{lcc}
\hline Year & Total charcoal production & Total emissions $\left(\mathrm{CO}_{2} \mathrm{e}\right)$ \\
\hline 2014 & 15096 & 24411.02 \\
2015 & 20282.2 & 32797.37 \\
2016 & 25060 & 40523.32 \\
2017 & 53270.0 & 86140.36 \\
2018 & 50940.0 & 82371.91 \\
\hline
\end{tabular}

production from their plantation and by purchasing from another farmer, $22 \%$ of the producers used wood from their eucalyptus plantation, and the remaining $12 \%$ of the producers used wood by purchasing from another farmer who had enough eucalyptus plantation.

It was revealed in Table 17 that Eucalyptus tree species accounted for more than $94 \%$ proportion of tree species preferred for charcoal production in the study area. The

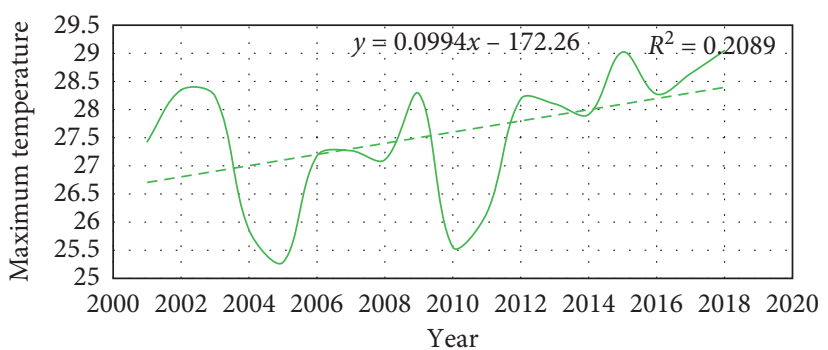

Figure 2: Trend of annual maximum temperature from 2000 to 2020.

reason behind choosing Eucalyptus tree species was the fastgrowing nature of Eucalyptus tree species and being easily available than other tree species. Acacia species accounted for $2.67 \%$ of wood sources for charcoal burning, and the remaining proportion of tree species which were Cordia africana and others accounted for $2 \%$ and $1.33 \%$, 


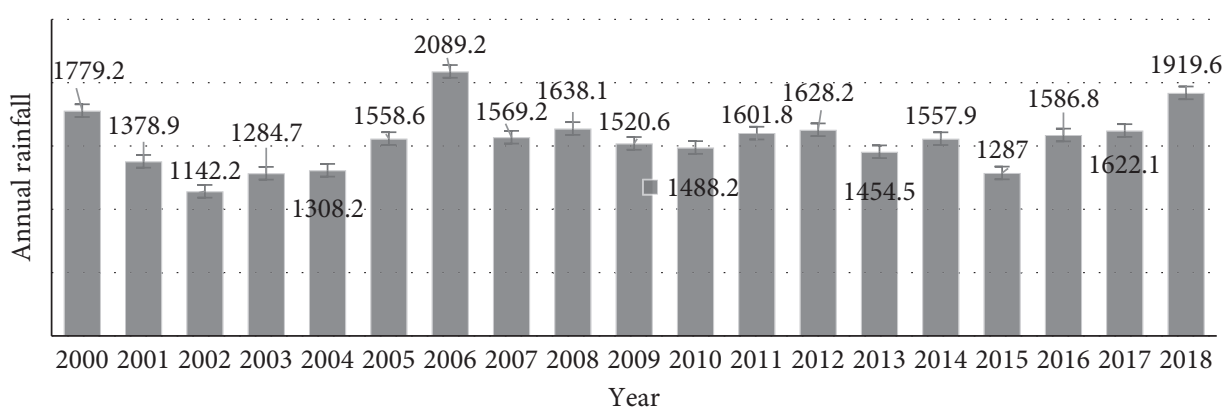

Figure 3: Trend hyacinths of annual rainfall from 2000 to 2018.

TABLE 15: Major reason behind choosing charcoal production rather than other activities.

\begin{tabular}{lcc}
\hline Variable & Frequency & Percentage \\
\hline Higher demand for charcoal & 6 & 4 \\
Higher income generation from charcoal product & 129 & 86 \\
To change eucalyptus tree trade waste to charcoal & 15 & 10 \\
Total & 150 & 100 \\
\hline
\end{tabular}

TABle 16: Source of wood for charcoal production.

\begin{tabular}{lcccc}
\hline Response & \multicolumn{2}{c}{ Source of wood for charcoal production } & \\
& Inherited & Purchased & $\begin{array}{c}\text { Purchased and } \\
\text { inherited }\end{array}$ & Total \\
\hline Frequency & 33 & 18 & 99 & 150 \\
Percentage & 22 & 12 & 66 & 100 \\
\hline
\end{tabular}

respectively. This result is different from Larinde and Olasupo [43] who discovered that the majority $(80 \%)$ of the respondents get wood for charcoal production from the natural forest, while about $20 \%$ of the respondents get their wood from forest reserves in Oyo State, Nigeria. In Nigeria, for charcoal production, with $73 \%$ of charcoal producers in the four villages preferring to use this species, it was revealed that Prosopis africana is widely used because it is hardwood; they further revealed that hardwoods give higher charcoal yield than softwoods [39].

More than $60 \%$ of the respondents accounted for those whose carbonization lasted for 6-7 days while less than 30\% accounted for those whose carbonization lasted for $8-10$ days. Carbonization is subject to the level of dryness of the wood and the quantity of wood used for charcoal production. As shown in Figure 4, the only production method practice in the study area was traditional earth-mound kilns methods which are a mound and are usually triangular and circular in shape. Charcoal is produced in mounds igniting the kiln and allows carbonization under limited air supply as shown in the photo.

The majority of charcoal-producing communities who participated in this study did not own the land where production took place. In most cases, the land was owned by a third party, and they rent from them, and the remaining were producing on common lands even near to social institutions like schools and health centers, roadsides, and settlements that exposed those parts of communities to smog pollution and critical health and safety problems, and they
TABle 17: Tree species used for charcoal burning.

\begin{tabular}{lcc}
\hline Variable & Frequency & Percentage \\
\hline Eucalyptus trees & 141 & 94 \\
Acacia species & 4 & 2.67 \\
Cordia africana & 3 & 1.33 \\
Others & 2 & 2 \\
Total & 150 & 100 \\
\hline
\end{tabular}

could not care for natural resource near to the kiln but few of them produce charcoal on their own land.

As represented in Table 18, the respondents used more than one laborer in their production. About $32.7 \%, 40 \%$, $15.3 \%$, and $12 \%$ of the respondents have laborers of $2,3,4$, and 5 , respectively, to themselves in the production.

As represented in Table 19, employed workers on charcoal production faced skin irritation/skin roasting problem by fire since the significance level of the $\mathrm{chi}^{2}$ analysis result is 0.002 . Also, employed laborers significantly faced respiratory illnesses like pneumonia, bronchitis, senescence, and other acute respiratory infections since the significance level of the $\mathrm{chi}^{2}$ analysis result is 0.000 . But they faced a slight problem of eye irritation since the significance level of the chi ${ }^{2}$ analysis result is 0.572 . This result is in line with the results of [42] who reported that dirty of their bodies and houses, sicknesses, generating smoke, and ash dust were the forms of social-economic impact being encountered.

As represented in Figure 5, pneumonia prevalence had an increasing trend from 2010 to 2012 and showed slight decrease in trend from 2012 to 2014 and then an increasing trend from 2016 to 2018. Generally, pneumonia prevalence had an increasing trend which implies that charcoal production had its own impact on pneumonia prevalence.

As represented in Figure 6, the acute respiratory infection had an increasing trend from 2010 to 2012 and showed also an increasing trend from 2014 to 2016 and then an increasing trend from 2016 to 2018. Generally, the acute respiratory infection had an increasing trend which implies 

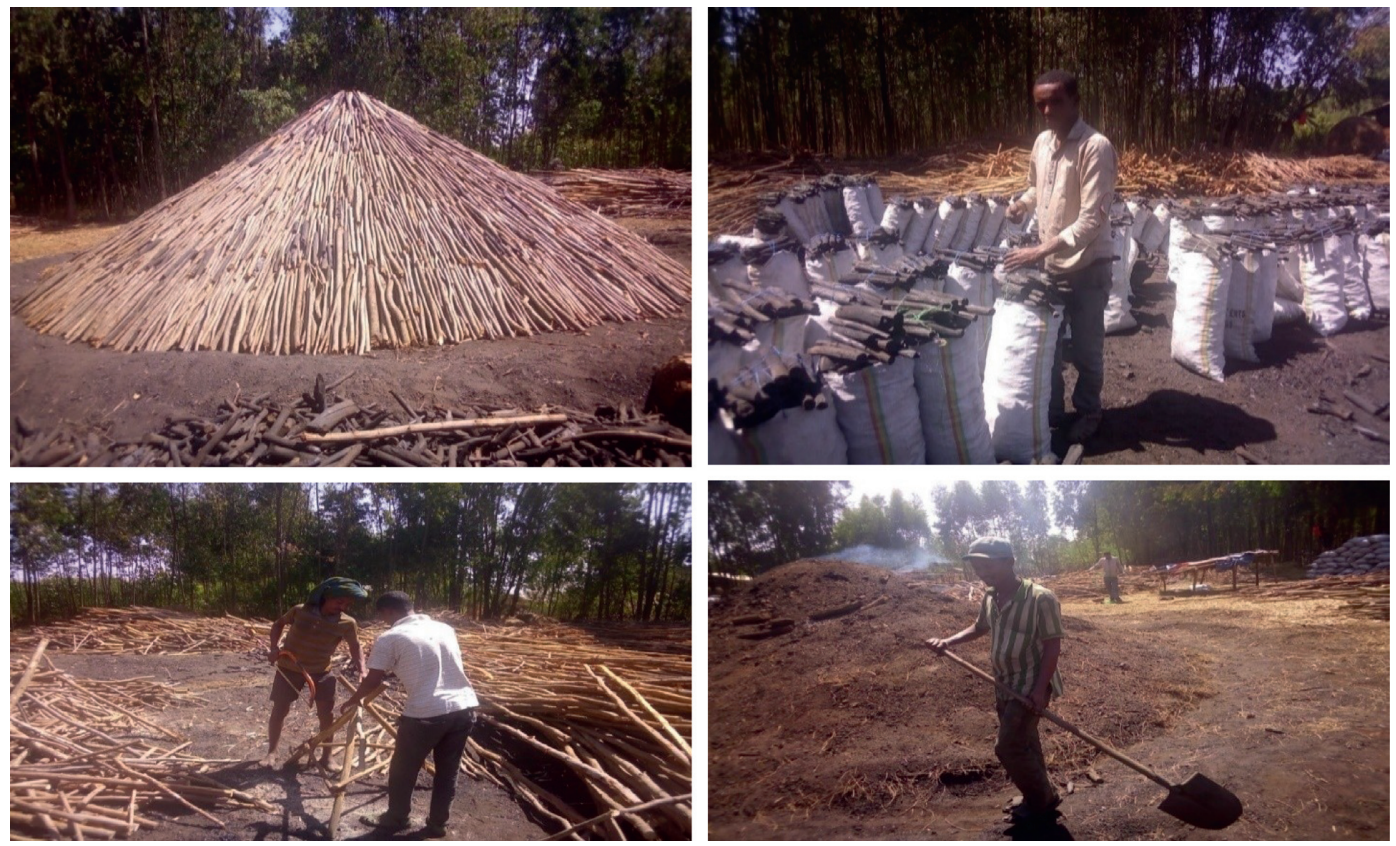

FIgURE 4: Charcoal production sites and process (source: observations (2019)).

TABLE 18: Number of laborers employed in charcoal production.

\begin{tabular}{|c|c|c|c|}
\hline \multirow{6}{*}{ Number of laborers employed in charcoal production } & Response & Frequency & Percentage \\
\hline & 2 persons & 49 & 32.7 \\
\hline & 3 persons & 60 & 40 \\
\hline & 4 persons & 23 & 15.3 \\
\hline & 5 persons & 18 & 12 \\
\hline & Total & 150 & 100 \\
\hline
\end{tabular}

TABle 19: Employed laborer health problem faced analyzed with chi-square.

\begin{tabular}{lcccc}
\hline & Response & Skin irritation & Eye irritation & Respiratory illness \\
& Yes & 36 & 27 & 38 \\
Do you face those health problems? & No & 14 & 23 & 50 \\
& Total & 50 & 0.572 & 12 \\
\hline
\end{tabular}

that charcoal production had its own impact on acute respiratory infection since $R^{2}=0.935$. Employed laborers on charcoal production were closely proximate to extreme temperature kilns during the production phase especially at night since the average distance between the sleeping area and burning kiln at night is only 5.2 meters. That exposed those laborers to adverse health risks related to charcoal production.

Based on the information gathered from the key informant interview, charcoal production started in the study area in 2011. As we get data from the district agriculture office, there is no licensed charcoal producer but they use tree trade license for charcoal production. Charcoal production kilns are also near to living house schools and roadsides as researchers observed in the study area. The observed environmental problems because of charcoal production in the study area as checked by observation and concluded from key informant interview were smog pollution, vision obstruction, roof rusting, soil and soil microorganism burning at kiln site deforestation, cause for

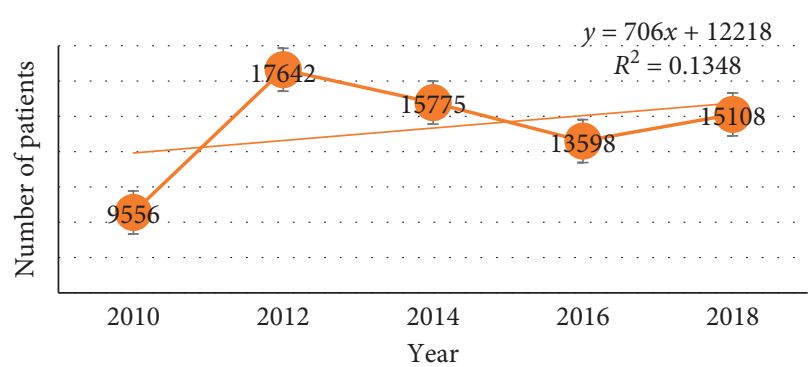

Figure 5: Pneumonia prevalence from 2010 to 2018 E.C.

traffic accident because of roadside crowdedness by a piece of wood and charcoal, dust and aerosol problem, welting of fruits and vegetables, and rainy season fluctuation.

\subsection{Impact of Charcoal Production on Households' Livelihood.} The logistic regression model was employed to estimate propensity scores for matching charcoal producer 


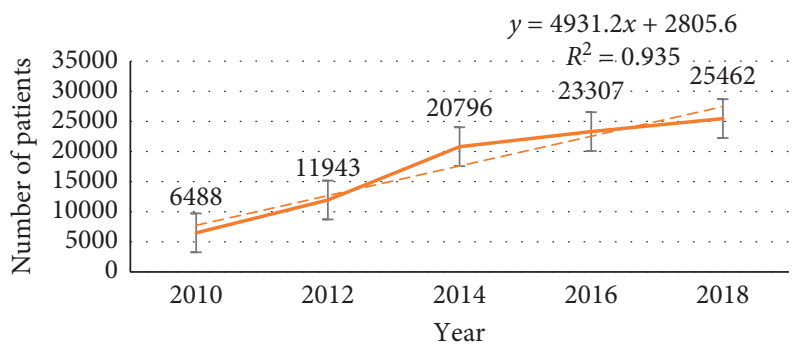

FIgURE 6: Acute respiratory infection from 2010 to 2018 E.C.

households with noncharcoal producer households. For estimating propensity scores, only those variables which affect both the likelihood of charcoal production participation and the income impact were included. The pseudo- $R^{2}$ value of 0.4075 shows that the overall explanatory variables included in the regression explain the dependent variable (socioeconomic impact of charcoal production) of about $40.75 \%$ which is fair for nonlinear econometric regression. The logistic regression model specified in equation (8) was employed to estimate propensity scores for matching displaced households with control or nondisplaced households. The dependent variable in this model was a dummy variable indicating whether the household has been displaced which takes a value of 1 and 0 , otherwise. For estimating propensity scores, only those variables which affect both the likelihood of displacement and the outcomes of interest were included.

The estimated regression results show in Table 20 that the probability of charcoal production participation is significantly and negatively affected by household land size, the number of oxen, extension service, and market distance from households' home, and these results are significant at $1 \%$ and $10 \%$ probability level, respectively. Likewise, it is positively affected by eucalyptus coverage which is significant at an equally $1 \%$ probability level.

$$
\begin{aligned}
\text { Number of observations } & =305, \\
\operatorname{LRchi}^{2}(10) & =172.27, \\
\text { Prob }>\operatorname{chi}^{2} & =0.0000, \\
\log \text { likelihood } & =-125.23307, \\
\text { Pseudo } R^{2} & =0.4075 .
\end{aligned}
$$

4.4.1. Household Land Size. As the model result indicates, the variable household land size had negatively and significantly influenced the charcoal production participation at less than $1 \%(P$ value $<0.001)$ probability level. This finding indicates that those farm households with higher farmland size are more likely to decrease charcoal than households with less land size (see Table 20).

4.4.2. Eucalyptus Coverage. Eucalyptus coverage has a statistically significant positive effect on charcoal production, and the result is significant at $1 \%(P$ value $<0.001)$. Even though charcoal producers have relatively lower land sizes than noncharcoal producers, they covered most of their land with eucalyptus and then produce charcoal. As eucalyptus coverage increases, the probability of participating in charcoal production activity increases (see Table 20).

4.4.3. The Number of Oxen. The number of oxen has a statistically significant negative effect on charcoal production, and the result is significant at $1 \%$ (Pvalue <0.001). Farm households who have a large number of oxen engaged in farming activity would increase especially in irrigation work rather than producing charcoal but farmers who have relatively small numbers of oxen highly engaged in charcoal production rather than farming activity. As the number of oxen increases, the probability of participating in charcoal production activity declined (see Table 20).

4.4.4. Extension Service. Extension service has a statistically significant negative effect on charcoal production, and the result is significant at $1 \%(P$ value $<0.001)$. As the extension service access increases, the probability of participating in charcoal production activity declined (see Table 20).

4.4.5. Market Distance. Market distance has a statistically significant negative effect on charcoal production, and the result is significant at $5 \%(P$ value $<0.012)$. As the market distance is far apart, the probability of participating in charcoal production activity declined (see Table 20).

4.5. Distribution of Propensity Score Matching. The distribution of propensity scores of both charcoal producers' and nonproducer's observations is presented in a graph shown in Figure 7. As represented in Figure 7, most charcoal producer households are found on the right side of the distribution, whereas most of the nonproducer households are found partly in the center and partly on the left side of the distribution. On the other hand, charcoal producer propensity score distribution was skewed to the right while it was skewed to the left side for nonproducer households. From the figures, one can observe that there is a wide area in which the propensity scores of both the treatment and the control groups are similar. Hence, it is possible to match the two groups using the common support region.

4.6. The Impacts of Charcoal Production on Farm Household Income. This section presents evidence as to whether or not charcoal production has brought significant changes to the 
TABLE 20: Logistic regression model result for charcoal production participation.

\begin{tabular}{|c|c|c|c|c|c|}
\hline Variables & Coef. & Std. err. & $Z$ & $P>|z|$ & [95\% conf. interval] \\
\hline Sex & 1.0861 & 0.9058607 & 1.20 & 0.231 & {$[-0.6893542-2.861555]$} \\
\hline Age & -0.2527549 & 0.3104656 & -0.81 & 0.416 & {$[-0.8612563-0.3557465]$} \\
\hline Family size & 0.1283652 & 0.157903 & 0.81 & 0.416 & {$[-0.1811189-0.4378494]$} \\
\hline Education status & 0.2491024 & 0.3127596 & 0.80 & 0.426 & {$[-0.3638952-0.8621001]$} \\
\hline Land size & -1.44551 & 0.4236064 & -3.41 & $0.001^{* *}$ & {$[-2.275763-0.6152568]$} \\
\hline Eucalyptus coverage & 7.287438 & 0.9916262 & 7.35 & $0.000^{* *}$ & [5.343887-9.23099] \\
\hline Number of oxen & -1.471818 & 0.3810437 & -3.86 & $0.000^{* *}$ & {$[-2.21865-0.7249858]$} \\
\hline Extension service & -1.533715 & 0.3889231 & -3.94 & $0.000^{* *}$ & {$[-2.29599-0.7714395]$} \\
\hline Credit service & 0.8906354 & 0.6276396 & 1.42 & 0.156 & {$[-0.3395157-2.120786]$} \\
\hline Market distance & -0.4654044 & 0.1858764 & -2.50 & $0.012^{*}$ & {$[-0.8297155-0.1010933]$} \\
\hline Marital status & -0.0139243 & 0.2785831 & -0.05 & 0.960 & {$\left[\begin{array}{ll}-0.5599371 & 0.5320885\end{array}\right]$} \\
\hline Constant & 1.462284 & 1.655139 & 0.88 & 0.377 & {$[-1.781728-4.706296]$} \\
\hline
\end{tabular}

Source: own survey $(2019){ }^{* *}=$ significant at $1 \%,{ }^{*}=$ at $5 \%$, and $n s=$ not significance levels, respectively.

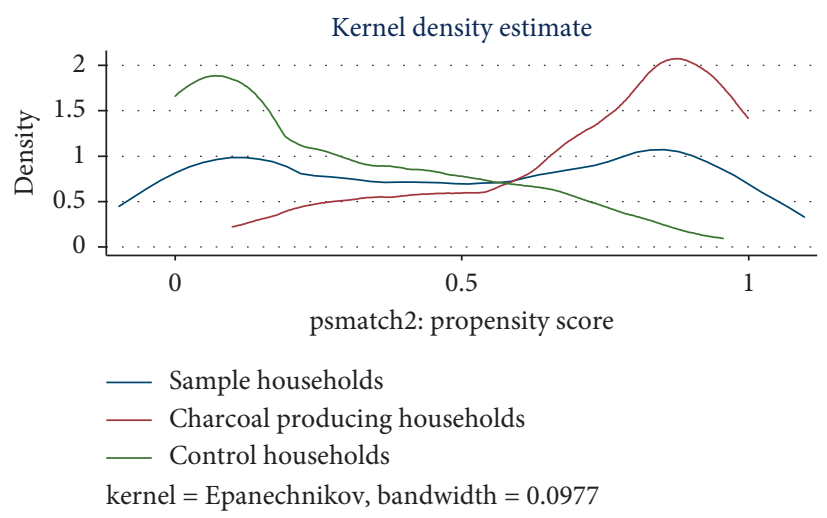

FIGURE 7: Common support estimation with kernel density.

TABLE 21: Impacts of urban expansion displacement on farming community.

\begin{tabular}{lcccrr}
\hline Outcome variables & Charcoal producer & Nonproducer & Difference & S.E & $T$-value \\
\hline HH livelihood outcome & 2.561822 & 2.123690612 & 0.43813162 & .038137446 & -2.057 \\
\hline
\end{tabular}

Source: estimation result, 2019.

annual income of the rural farming communities. After controlling the other characteristics, the propensity score matching model using the nearest neighbor matching estimator result (bandwidth 4) indicates an urban expansion effect from the propensity score matching estimation (in Table 21) which shows that there is a significant difference in the annual income of charcoal production farming community by 0.43813162 as compared to the nonproduced farming community.

\section{Conclusion}

The majority of the charcoal producers get wood for charcoal production both from their plantation and by purchasing from another farmer. The reason behind choosing charcoal production as the primary occupation was the higher income generation from charcoal production. The total annual charcoal production, rate, and total emission of $\mathrm{CO}_{2} \mathrm{e}$ had increased at an alarming rate $(24411.02$ by $2014,32797.37$ by $2015,40523.32$ by $2016,86140.36$ by 2017 , and 82371.9 by 2018). As a result, the annual minimum temperature and annual maximum temperature also increase after charcoal production started in that area but the annual rainfall had some fluctuation. The producers were using more than one laborer in their production, and also, some of them were child laborers. The social and public health risks associated with charcoal production were clearly identified in this study. Most laborers employed in charcoal production not used personal protective equipment that increases the risk of exposure to health and safety problems. socioeconomic factors like land size, eucalyptus coverage, agricultural extension market distance, and the number of oxen have a statistically significant effect but other factors like sex, age, family size, education status, and credit service have no statistically significant effect on charcoal production. Charcoal production was economically profitable in the study area, while charcoal production is economically valuable; it has disproportionately adverse effects on environmental degradation and local air quality contamination in addition to respiratory health problems for producers and nearby residents. So, the utilization of high-efficiency kilns made of metal and brick can significantly lower the impacts 
associated with an industry that is vital to the national economy. In light of the 2015 Sustainable Development Goals and numerous findings across the continent, the results of this study and others suggest that an exclusive focus on modern energy services should be redirected to consider these traditional and widespread energy sources that have significant economic, environmental, and social impacts.

\section{Data Availability}

Data and publications from this project will be of open access and available via an online repository.

\section{Conflicts of Interest}

The authors declare that they have no conflicts of interest.

\section{References}

[1] W. A. Onekon and K. O. Kipchirchir, "Assessing the effect of charcoal production and use on the transition to a green economy in Kenya," Tropical and Subtropical Agroecosystems, vol. 19, no. 3, pp. 327-335, 2016.

[2] A. Ghilardi and F. Steierer, "Charcoal production and use: world country statistics and global trends," in Proceedings of the Symposium on the Role of Charcoal in Climate Change and Poverty Alleviation Initiatives, Arushai, Tanzania, June 2011.

[3] B. Okello, T. O'connor, and T. P. Young, "Growth, biomass estimates, and charcoal production of Acacia drepanolobium in Laikipia, Kenya," Forest Ecology and Management, vol. 142, no. 1-3, pp. 143-153, 2001.

[4] E. Chidumayo, "Environmental impacts of charcoal production in tropical ecosystems of the world," in Proceedings of the Meetings of the Association of Tropical Biology and Conservation, Arusha, Tanzania, April 2011.

[5] R. T. Kappel and E. K. Ishengoma, Economic Growth and Poverty: Does Formalisation of Informal Enterprises Matter?, German Institute for Global and Area Studies (GIGA), Hamburg, Germany, 2006.

[6] L. C. Zulu and R. B. Richardson, "Charcoal, livelihoods, and poverty reduction: evidence from sub-Saharan Africa," Energy for Sustainable Development, vol. 17, no. 2, pp. 127-137, 2013.

[7] A. Ellegård and M. Nordström, "Deforestation for the poor?" Renewable Energy for Development, vol. 16, no. 2, pp. 4-6, 2003.

[8] M. O. Dioha and A. Kumar, "Exploring sustainable energy transitions in sub-Saharan Africa residential sector: the case of Nigeria," Renewable and Sustainable Energy Reviews, vol. 117, Article ID 109510, 2020.

[9] S. Lurimuah, The Economic and Environmental Effects of Commercial Charcoal Production in the Upper West Region of Ghana, 2011.

[10] J. Mohammed, I. Tetteh, and M. Mills, "Fuelwood to charcoal production in the new juaben municipality of the eastern region of ghan challenges and opportunities in seeking livelihood," Researchers World, vol. 4, no. 4, p. 51, 2013.

[11] V. Bustamante-García, A. Carrillo-Parra, H. GonzálezRodríguez, R. G. Ramírez-Lozano, J. J. Corral-Rivas, and F. Garza-Ocañas, "Evaluation of a charcoal production process from forest residues of Quercus sideroxyla Humb., and Bonpl. in a Brazilian beehive kiln," Industrial Crops and Products, vol. 42, pp. 169-174, 2013.
[12] P. M. Fearnside and W. F. Laurance, "Tropical deforestation and greenhouse-gas emissions," Ecological Applications, vol. 14, no. 4, pp. 982-986, 2004.

[13] M. Arnold and R. Persson, "Reassessing the fuelwood situation in developing countries," International Forestry Review, vol. 5, no. 4, pp. 379-383, 2003.

[14] I. M. Amugune, Technological Factors Influencing the Quality and Quantity of Charcoal Produced in Western Mau Forest, Kericho County, Kenya, Africa Nazarene University, Nairobi, Kenya, 2020.

[15] V. Chiteculo, B. Lojka, P. Surový, V. Verner, D. Panagiotidis, and J. Woitsch, "Value chain of charcoal production and implications for forest degradation: case study of bié province, Angola," Environments, vol. 5, no. 11, p. 113, 2018.

[16] Y. Alem et al., Household Fuel Choice in Urban Ethiopia: A Random Effects Multinomial Logit Analysis, 2013.

[17] H. Geller, R. Schaeffer, A. Szklo, and M. Tolmasquim, "Policies for advancing energy efficiency and renewable energy use in Brazil," Energy Policy, vol. 32, no. 12, pp. 1437-1450, 2004.

[18] K. R. Smith, "Indoor air pollution in developing countries: recommendations for research+," Indoor Air, vol. 12, no. 3, pp. 198-207, 2002.

[19] M. A. Mulugeta, Linking Fiscal Decentralization and Local Financial Governance: A Case of District Level Decentralization in the Amhara Region, Ethiopia, University of Western Cape, Cape Town, South Africa, 2014.

[20] M. Getahun, Characterisation of Agricultural Soils in Cascape Intervention Woredas of Amhara Region, 2015.

[21] M. D. A. Office, The Population of the District Based the Ethiopia Central Statistical Agency Census Conducted in 2010, 2010.

[22] W. G. Cochran, "The estimation of sample size," Sampling Techniques, vol. 3, no. 1, pp. 72-90, 1977.

[23] W. G. Cochran, Sampling Techniques-3, Wiley, Hoboken, NJ, USA, 1977.

[24] R. V. Krejcie and D. W. Morgan, "Determining sample size for research activities," Educational and Psychological Measurement, vol. 30, no. 3, pp. 607-610, 1970.

[25] S. K. Antwi and K. Hamza, "Qualitative and quantitative research paradigms in business research: a philosophical reflection," European Journal of Business and Management, vol. 7, no. 3, pp. 217-225, 2015.

[26] IPCC III, W., Third Assessment Report. Summary for Policymakers, IPCC, Geneva, Switzerland, 2001.

[27] IPCC, 2006 IPCC Guidelines for National Greenhouse Gas Inventories, IGES, Kanagawa Japan, 2006.

[28] M. Caliendo and S. Kopeinig, "Some practical guidance for the implementation of propensity score matching," Journal of Economic Surveys, vol. 22, no. 1, pp. 31-72, 2008.

[29] B. E. Frye and J. E. Bartlett, "Performing the PSM analysis: an applied example," Journal of Applied Research in the Community College, vol. 24, no. 1, pp. 43-58, 2017.

[30] S. Yang, "Propensity score weighting for causal inference with clustered data," Journal of Causal Inference, vol. 6, no. 2, 2018.

[31] N. L. P. Nguyen, Essays on Propensity Score Methods for Causal Inference in Observational Studies, Duke University, Durham, North Carolina, 2018.

[32] A. Gujarati, Basic Econometrics, The McGraw-Hill companies, Pennsylvania, NY, USA, Fourth edition, 2004.

[33] J. J. Diaz and S. Handa, "An assessment of propensity score matching as a non experimental impact estimator: evidence from a Mexica's PROGRESA program," The Journal of $\mathrm{Hu}$ man Resources, vol. 41, no. 2, pp. 319-345, 2004. 
[34] J. A. Smith and P. E. Todd, "Does matching overcome LaLonde's critique of nonexperimental estimators?" Journal of Econometrics, vol. 125, no. 1-2, pp. 305-353, 2005.

[35] J. J. Heckman, H. Ichimura, and P. Todd, "Matching as an econometric evaluation estimator," Review of Economic Studies, vol. 65, no. 2, pp. 261-294, 1998.

[36] R. Blundell and M. Costa Dias, "Evaluation methods for nonexperimental data," Fiscal Studies, vol. 21, no. 4, pp. 427-468, 2000.

[37] P. R. Rosenbaum and D. B. Rubin, "The central role of the propensity score in observational studies for causal effects," Biometrika, vol. 70, no. 1, pp. 41-55, 1983.

[38] J. J. Heckman, H. Ichimura, and P. E. Todd, "Matching as an econometric evaluation estimator: evidence from evaluating a job training programme," The Review of Economic Studies, vol. 64 , no. 4 , pp. 605-654, 1997.

[39] O. Adeniji, O. S. Zaccheaus, B. S. Ojo, and A. S. Adedeji, "Charcoal production and producers' tree species preference in Borgu local government area of Niger State, Nigeria," Journal of Energy Technologies and Policy, vol. 5, no. 11, pp. 1-8, 2015.

[40] J. Bhattarai, E. Akiyama, H. Habazaki et al., "The passivation behavior of sputter-deposited W-Ta alloys in $12 \mathrm{M} \mathrm{HCl,"}$ Corrosion Science, vol. 40, no. 4-5, pp. 757-779, 1998.

[41] J. Ogara, "Preliminary studies on charcoal production and producers' knowledge of environmental hazards in Nasarawa State, Nigeria," PATS, vol. 7, pp. 68-75, 2011.

[42] A. V. Goanue, Status of Renewable Energy in Liberia, Presentation of Rural and Renewable Energy Agency, 2009.

[43] S. Larinde and O. Olasupo, "Socio-economic importance of fuelwood production in Gambari forest reserve area, Oyo State, Nigeria," Journal of Agriculture and Social Research (JASR), vol. 11, no. 1, 2011. 